\title{
THE EFFECT OF CORPORATE SOCIAL RESPONSIBILITY (CSR) ON INCREASING THE COMPETITIVENESS OF SMALL AND MEDIUM ENTERPRISES (SMES) IN OKU TIMUR, INDONESIA
}

\author{
Helisia Margahana \\ Sekolah Tinggi Ilmu Ekonomi Trisna Negara, Sumatera Selatan \\ Email :helisia.tn@gmail.com
}

\begin{abstract}
The purpose of this study is to determine whether Corporate Social Responsibility (CSR) affects the Competitiveness of Small and Medium Enterprises (SMEs). The population in this study are consumers who use e-commerce media in the South Sumatra area. The sample in this study was 200 respondents who were random samples from the Small and Medium Enterprises in South Sumatra. This study uses a survey method to see the amount of influence caused by the independent variables on the dependent variable. The independent variable examined in this study is the Corporate Social Responsibility (CSR) variable. The dependent variable in this study is the Competitiveness of Small and Medium Enterprises (SMEs). Based on the results of the study it can be seen that Corporate Social Responsibility (CSR) affects the Competitiveness of Small and Medium Enterprises (SMEs). So it can be concluded that if a business or business follows the regulations of the government, runs it and implements it based on predetermined factors, including work orientation factors, market orientation factors, and environmental orientation factors, then the business will be better known by the stakeholders and will be more competitive in the long run. Therefore SMEs must continue to consult with the government regarding CSR activities, which factors of CSR are most beneficial for all parties in business activities. SMEs must also focus on factors of price competition and competitive advantage to improve the image of SMEs and enhance competitiveness.
\end{abstract}

Keyword : CSR, Competitiveness, SMEs

\section{Introduction}

In the business world, companies often deal with stakeholders. Stakeholders are used by business people in carrying out economic activities. Rhenald Kasali in Kirana (2009) stakeholders are groups within and outside the company that has a role in determining the success of the company. They consist of suppliers, customers, governments, local communities, investors, employees, groups, politics, trade associations and others.

Based on the World Business Council for Sustainable Development (WBCSD, 1999) Corporate Social Responsibility (CSR) is a commitment from a business or company to behave ethically and contribute to sustainable economic development. In addition, CSR can improve the standard of living of individuals and their families, as well as organizations. CSR is not only carried out by large companies but also is carried out by micro, small and medium- sized companies. 
Currently the role of Small and Medium Enterprises (SMEs) is very important in improving the economy of a country, including Indonesia. SMEs are very instrumental in increasing Gross Domestic Product (GDP) and providing employment for the community and reducing the number of unemployed in Indonesia. The Indonesian Chamber of Commerce and Industry considers that Small and Medium Enterprises (MSMEs) have a very vital role in maintaining economic growth. In fact, he is able to create jobs that can reduce poverty. The Indonesian Chamber of Commerce and Industry noted the contribution of the MSME sector to gross domestic product (GDP) increased from initially 57.84 percent to 60.34 percent in the last five years. The impact of this increase was the increase in employment from 96.99 percent to 97.22 percent at the same time. Roeslani (Republika, 11 February 2020).

Aryani (2011) competitiveness is the ability to show better performance, faster and more meaningful. While Porter in Putri (2012) competitiveness is defined as the company's business ability to deal with various environments encountered. Competitiveness is determined by the competitive advantage of a company and depends on the level of relative resources owned by the company or often referred to as a competitive advantage. Porter's (2008) competition is very tight for the success or failure of a company. Therefore, to face increasingly fierce competition, every company must be able to read its opportunities and competitiveness. Hasan (2015) The company's competitive performance is defined as input and output. Input measures are based on physical (facilities, infrastructure, and environment), people (services), research and development costs, and marketing and promotion costs. While outputs include profitability, market control, productivity, and growth. According to Porter in Yulianto (2013) indicators that can measure competitiveness include competitive prices, product quality, and competitive advantage.

The era of globalization is full of uncertainties, social and political and economic turmoil that often occur can affect the course of the organization (Martinez, 2015), Werther, 2010). The existence of CSR reflects the need for certification to increase the competitiveness of companies (Lee, 2008). In the mid-twentieth century the concept of Corporate Social Responsibility (CSR) was introduced for the first time and studied, so that it has developed over the last few decades (Carrol, 2010). CSR produces benefits for the organization in the form of community welfare, sustainability, the rights of employees or workers, and the development of human resources up to profits by the company (Blowfield, 2008, Carroll, 2008). However, studies on Corporate Social Responsibility in Small and Medium Enterprises are felt to be very little (Carroll, 2008, Lee, 2008).

Several previous studies have tried to analyze the role of CSR in enhancing the competitiveness of SMEs including: Turyakira et al (2012) which states that CSR oriented to the workforce, and small communities can significantly affect the competitiveness of SMEs. Jorge (2016) said that companies will increasingly integrate CSR and quality management practices to meet the needs of stakeholders, the most common social and environmental practices facilitating development within the company. Juarez (2017) Corporate Social Responsibility has an influence on increasing the competitiveness of SMEs. The results of this study can be used to develop theories about the practice of Corporate Social Responsibility. Marnelly (2012) the concept of Corporate Social Responsibility is emphasizing organizational responsibility not only about profitability, but also about social and community. They assume that a financially oriented attitude cannot guarantee the health of the company. Corporate Social Responsibility can be done through the development of Small Medium Enterprises based on real needs that are dialogically communicated with the community, government, companies, communities, and academics. 


\section{Theoretical Framework And Hypotheses}

\subsection{Corporate Social Responsibility (CSR)}

Based on the literature states that the concept of CSR began to develop during the last two decades. However, other literatures which focus exclusively on the output of economic performance are primarily the financial sector (Friedman, 2007). Kramer (2006) and Friedman (2007) are of the view that CSR practices in organizations in the form of social actions, and altruistic actions cannot be applied, or very few are successful.

In the era of globalization, where social, political and economic uncertainties now have a profound effect on organizations (Martinez, 2015, Werther, 2010). The current concept of CSR requires certification to improve the competitiveness of companies or organizations (Lee, 2008). Some studies still adhere to the concept of CSR based on the company's commitment to society and organizations to achieve company performance (Bowen, 2013). Carrol (2014) states that CSR is closely related to the profits of the company. To be able to improve company performance, CSR must be based on economic, legal, ethical and policy perspectives. Also, organizational practices that focus on maintaining and protecting the environment are important for achieving better organizational results (OECT, 2011).

In the context of empowering and enhancing the competitiveness of MSMEs, the government has issued regulations for SOEs to set aside part of their profits for the SCR (Corporate Social Responsibility) program. The Republic of Indonesia Government Regulations for SOEs (State- Owned Enterprises) companies must set aside 2 percent of their net profit after deducting taxes as operational funds for implementing corporate social responsibility (Ministerial Regulation Number per-05 / MBU / 2007). In addition, the government also conducts programs on social responsibility of SOE companies, namely the Partnership with Small Business Program and the Community Development Program (Ministerial Regulation Number per-05 / MBU / 2007).

The development of partnership programs with CSR patterns can be done with various patterns, such as community development, capacity building, product promotion, and even capital strengthening for Micro and Small and Medium Enterprises (Soegiastutik, 2012).

\subsection{Competitiveness}

Porter in Surachman (2007) competitiveness is the ability or excellence used to compete in certain markets. According Tumihardjo (2008) competitiveness means power, can do more than others, can do differently from others in terms of quality and quantity. Strength in the sense of having advantage. In other words, competitiveness can be interpreted as the power to do the best, done together in groups and organizations. Afriyani (2011) competitiveness is the ability of individuals or groups to produce better, faster, and more meaningful performance for individuals and groups. While Porter in Putri (2012) competitiveness is defined as the company's business ability to deal with various environments encountered. Competitiveness is determined by the competitive advantage of a company and depends on the level of relative resources owned by the company or often referred to as a competitive advantage. Porter's (2008) competition is very tight for the success or failure of a company. Therefore, to face increasingly competitive competition, every company must be able to read its opportunities and competitiveness. Hasan (2015) The company's competitive performance is defined as input and output. Input measures are based on physical (facilities, infrastructure, and environment), people (services), research and development costs, and marketing and promotion costs. While 
outputs include profitability, market control, productivity, and growth. According to Porter in Yulianto (2013) indicators that can measure competitiveness include competitive prices, product quality, and competitive advantage.

\subsection{Small and Medium Enterprises (SMEs)}

Understanding of small and medium businesses in Indonesia is still diverse. Small Business and Micro Business are business entities that have a maximum fortune of two hundred million rupiah, not including buildings as business land, or have annual sales of at most one billion rupiahs, while Medium Enterprises are business entities by citizens who have a net worth of more than two hundred million rupiah to ten billion rupiah, not including buildings for business. According to the Central Statistics Agency for SMEs is a business entity that employs a maximum of 19 employees (Raselawati, 2011).

According to Law No. 9 of 1995 what is meant by small businesses that are productive businesses that are small scale and meet the criteria of net worth at most Rp. 200,000,000 excluding land and buildings for businesses or having a maximum of Rp. 1,000,000,000 per year and can receive credit from banks with a maximum of more than Rp. 50,000,000 to Rp. $500,000,000$.

While what is meant by Medium Enterprises according to Presidential Instruction No. 5 of 1998 is a productive business that meets the criteria for net business assets greater than Rp. 200,000,000 to a maximum of Rp. 10,000,000,000 excluding land and buildings for business and can receive credit from banks in the amount of Rp. 500,000,000 to Rp. 5,000,000,000. (UUD RI No. 9 of 1995, Chapter 2, Article IV concerning SMEs. Http://hukum.unsrat.ac.id/uu/uu_9_1995 .pdf)

The characteristics of Small and Medium Enterprises (SMEs) include: easily get ingredients to be sold, and can use simple technology so that transfer technology is easy to do, basic skills are generally owned for generations, are labor- intensive or absorb a large workforce, market opportunities are quite extensive, most of the products are absorbed in the domestic market has not been fulfilled, while others have the potential to export, involving small and medium businesses, so that it will be economically profitable. (Rahmana, 2009).

Small and Medium Business Development has several comparative advantages over large businesses. These advantages include the terms of capital, the development of small businesses requires relatively small business capital, the technology used does not need high technology, so the establishment is relatively easier than large businesses. The motivation of small businesses will be greater, given life and death depends on the only business. Someone with high survival motive will certainly be more successful. Also, the existence of a strong emotional bond with his business will increase the strength of small entrepreneurs in competition. Nitisusatro (2018).

Based on the model of mind-set, this study hypothesizes that it is suspected that there is an influence of CSR advertising with its indicators of work orientation, community orientation, market orientation and environmental orientation towards the interest in increasing the competitiveness of SMEs in South Sumatra. Based on the literature review and previous research, a conceptual framework of research can be made as follows: 


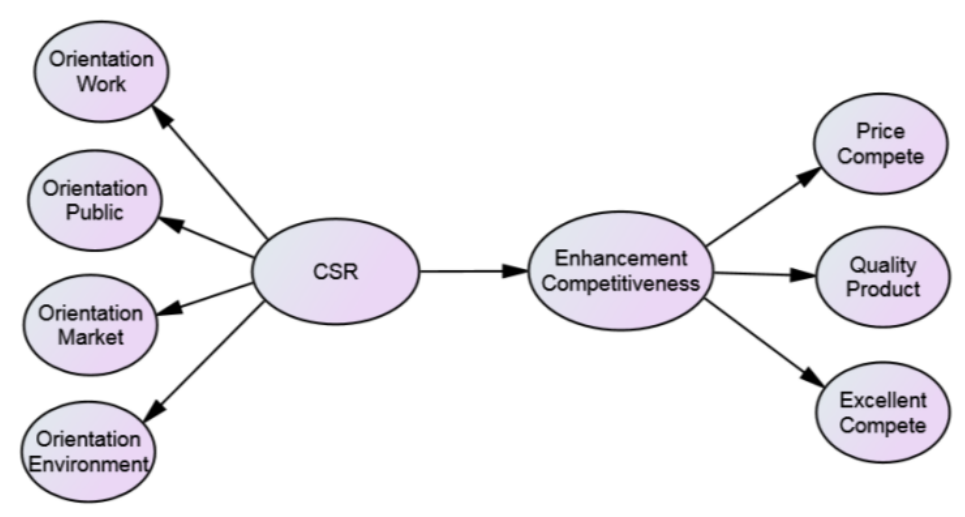

Figure 1. Research Conceptual Framework

\section{Research Method}

The population in this study is the Small and Medium Enterprises (SMEs) in the South Sumatra region. Samples taken were 200 respondents. This study is a quantitative study, which uses valid and reliable instruments on the Effect of CSR on the Competitiveness of SMEs in South Sumatra. Analysis of research data using descriptive and inferential statistical methods. Analysis models assisted with AMOS version 20 statistical analysis tool, which is a program of Structural Equation Modeling (SEM).

\section{Data Analysis And Discussion}

Based on a survey distributed to 200 respondents the questionnaire was filled in completely. All research variables were tested with goodness of fit index (GOF). The measurement model of the research variable uses a validity test to test whether each indicator is valid or not. In this study also uses the Maximum Likelihood Estimation (MLE) technique. To examine the relationship or influence between variables, Confirmatory Factor Analysis (CFA) analysis is used.

Based on the CFA test shown in Table 1, the loading factor value in the estimate column for each question item is greater than 0.5 , which concludes that all question items are valid. In Table 2 shows the value of C.R. greater than 0.7, and the value of V.E. greater than 0.5. This explains that all variables have reliable and trusted coefficients. And the CFA results concluded that all research indicators can be used to measure and analyze research variables.

Table 1. Validity Test Results Based on the Fit Model Standardized Regression Weights: (Group number 1 - Default model)

\begin{tabular}{|l|l|l|r|l|}
\hline & & & Estimate & Hasil \\
\hline Competitive & $<---$ & CSR & .984 & Valid \\
\hline OE & $<---$ & CSR & .467 & Valid \\
\hline OM & $<---$ & CSR & .807 & Valid \\
\hline OW & $<---$ & CSR & .597 & Valid \\
\hline PC & $<---$ & Competitive & .640 & Valid \\
\hline EC & $<---$ & Competitive & .629 & Valid \\
\hline
\end{tabular}




\section{E-ISSN: 2614-1280 P-ISSN 2622-4771}

http://jurnal.stie-aas.ac.id/index.php/IJEBAR

Table 2. Reliability Test Results Based on the Fit Model Squared Multiple Correlations: (Group number 1 - Default model)

\begin{tabular}{|l|r|}
\hline & Estimate \\
\hline Competitiveness & .969 \\
\hline
\end{tabular}

In the research hypothesis analysis test, AMOS version 20. Based on the fit hypothesis testing can be seen in Figure 1. While in Table 3 the assumptions of the analysis results are explained. Based on the model fit test, it can be said that the model meets the goodness of fit (GOF) criteria.

Based on GOF testing obtained Probability: 0.119, Chi-Square: 7.336, GFI: 0.986, AGFI: 0.949, NFI: 0.968, CFI: 0.985, RMSEA: 0.06, RMR: 0.02, where all GOF criteria meet the required cut-off. The results of this study indicate in accordance with the hypothesis proposed by the researcher.

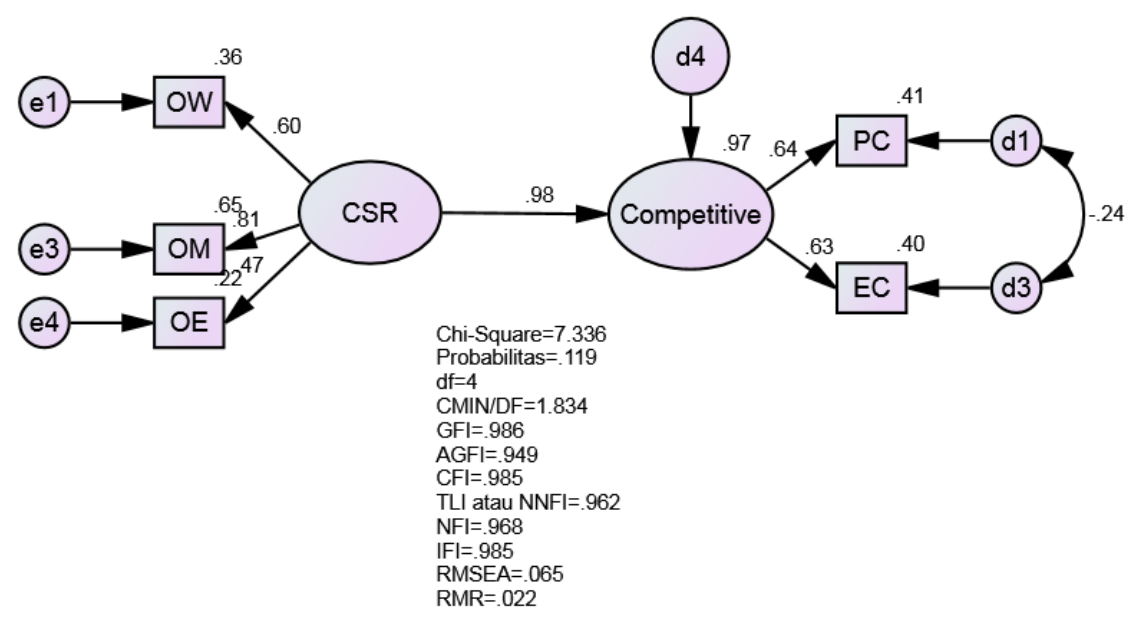

Figure 1. Effects of CSR on Increasing SME Competitiveness in South Sumatra

Table 3. Structural Parameters Estimating Direct Effects: Path Analysis Model Regression Weights: (Group number 1 - Default model)

\begin{tabular}{|ll|rrrrc|}
\hline & & Estimate & S.E. & C.R. & P & Label \\
\hline Competitiveness & $<---$ & $\mathbf{1 . 5 4 8}$ & $\mathbf{. 2 9 8}$ & $\mathbf{5 . 1 9 4}$ & $* * *$ & par_4 \\
CSR OE & $<---$ & 1.000 & & & & \\
CSR OM & $<---$ & 1.847 & .307 & 6.011 & $* * *$ & par_1 \\
CSR OW & $<---$ & 1.396 & .259 & 5.395 & $* * *$ & par_2 \\
CSR PC & 1.000 & & & & \\
Competitive & $<---$ & .837 & .136 & 6.162 & $* * *$ & par_3 \\
\hline
\end{tabular}

Testing the hypothesis in this study concluded that there is a positive and significant effect influence of CSR on competitiveness. Based on the value (C.R. or $t=5.194>1.96$ ) or the probability value $\mathrm{p}=$ with a sign which means very significant $* * *$. The results show that CSR 
Peer Reviewed - International Journal

Vol-4, Issue-2, 2020 (IJEBAR)

\section{E-ISSN: 2614-1280 P-ISSN 2622-4771}

http://jurnal.stie-aas.ac.id/index.php/IJEBAR

has a positive and significant impact on SMEs' competitiveness in line with previous studies by Turyakira et al (2012), Zhao (2019), Loikkanen (2011), Serbanica (2016), Novarinda (2016), and Soegiastuti (2012). The empirical results from their research show that CSR activities that are labor-oriented, CSR activities that are community-oriented, CSR activities that are market-oriented, and CSR activities that are regulated significantly affect the competitiveness of SMEs.

The findings in this study confirm a positive relationship between CSR and all its indicators (work orientation, market orientation, and environmental orientation) on increasing competitiveness (competitive prices and competitive advantage) Small and Medium Enterprises in South Sumatra. However, the results of this study also reveal that there is no need for indicators of CSR (community orientation factors) and indicators of Competitiveness (product quality factors) in the relationship of CSR to Increasing the competitiveness of SMEs in South Sumatra.

Based on the output of this study indicate that businesses that believe in work objectives, believe in the ability of employees, believe in the ability of the company, believe in employee development, provide security to employees while working, will increase the company's increasing the competitiveness of sustainable SMEs. SMEs are encouraged to continue to innovate and be creative, through various activities, such as training, and so on. SMEs are expected to provide a comfortable, safe and conducive place of business. SMEs are also asked to be responsible and fair to business partners thus providing more motivation to employees so that they will maintain a competitive advantage.

\section{Conclusion, And Suggestion}

The results of testing the research hypothesis indicate that there is a positive and significant influence of CSR activities on increasing the competitiveness of SMEs in South Sumatra. Based on the test results in this study, it can be concluded if a business follows government regulations, runs it and applies it based on established factors, including work orientation, market orientation, and environmental orientation, the business will be better known by stakeholders and will more competitive in the long run. Therefore SMEs must continue to consult with the government regarding CSR activities, which factors of CSR are most beneficial for all parties in business activities. SMEs must also focus on price competition and competitive advantage to improve the image of SMEs and enhance competitiveness.

\section{References}

Ariefianto Lutfi, 2015. Program Corporate Social Responsibility (CSR) PT Semen Indonesia Tbk dan Dampaknya Terhadap Keberdayaan Masyarakat. FKIP Universitas Jember. Jurnal Pancaran, Vol. 4 No. 2, hal. 115-134.

Dewi Restu Tia, 2018. Pengaruh Program SCR PT Jasa Raharja (Persero) Cabang Riau Terhadap Keberhasilan UMKM di Kota Pekanbaru. JOM FISIP Vol. 5 No. 1- April.

Garaika, Margahana Helisia, 2019. The Influence of Credibility and Voluntariness Toward Technological Use Behavior: Entrepreneurial Potential Model Approach. International Journal of Entrepreneurship, Vol. 23, pp. 1-9 
International Journal of Economics, Business and Accounting Research (IJEBAR)

Peer Reviewed - International Journal

Vol-4, Issue-2, 2020 (IJEBAR)

E-ISSN: 2614-1280 P-ISSN 2622-4771

http://jurnal.stie-aas.ac.id/index.php/IJEBAR

Garaika, Margahana Helisia, , 2019. Self Efficiency, Selft Personality and Selft Confidence on Entrepreneurial Intention: Study on Young Enterprises. Journal of Entrepreneurship Education.

Jorge Larran Manuel, Madueno Herrera Jesus, Sancho Lechuga Paula Maria, and Martinez Domingo, 2016. Development of Corporate Social Responsibility in Small and MediumSized Enterprises and its Nexus with Quality Management. Cogent Business \& Management.

Juarez Valdez Enrique Luis, 2017. Corporate Social Responsibility: Its Effect on SMEs. Journal Management and Sustainability, Vol. 7 No. 3.

Loikkanen Torsti and Hyytinen Kirsi, 2011. Corporate Social Responsibility and Competitiveness - Empirical Result and

Future Challenges. Envoromental Management Accounting and Supply Chain Management, Eco-Efficiency in Industry and Science 27.

Margahana Helisia, Erianto, Liestyana Yuli and Utami Yekti, 2019. Information Sharing, Supplier Performance, Supplier Trust, and Supplier Sinergy on Retailer. International Conference of Business, Economy, Entrepreneurship, and Management. Vol. 1, pp. 66

Margahana Helisia, Garaika, 2019. The Influence of Credibility and Voluntariness Toward Technological Use Behavior: Entrepreneurial Potential Model Approach. International Journal of Entrepreneurship. Vol. 23, Issue 2, pp.1-9 .

Margahana Helisia, Haryono Siswoyo, and Mustafa Zainal, 2018. The Effect of Job Motivation and Job Satisfaction Toward Organizational Citizenship Behavior (OCB) and Its Impact on Job Performance of Paramedical Community Health Centers in Bandar Lampung. Journal of Resources Development and Management. Vol. 46, pp. 1-10.

Marnelly T Romi, 2012. Corporate Social Responsibility (CSR): Tinjauan Teori dan Praktek di Indonesia. Pekanbaru. Jurnal Aplikasi Bisnis, Vol. 2 No. 2- April

Nitisusatro, Mulyadi, 2013. Perilaku Konsumen dalam Persepektif Kewirausahaan, Bandung. Alfabeta. Novarinda Lysia, 2016. Penerapan Strategi Corporate Social Responsibility (CSR) untuk Memperkuat Pengelolaan dan Pengembangan UMKM (Study Kasus pada UMKM "Almira Hand Made") di Malang. National Conference On Economic Education, Malang. Universitas Negeri Malang.

Rahmana Arief, 2009. Peranan Teknolgi Informasi dalam Peningkatan Daya Saing Usaha Kecil Menengah. Yogyakarta, Seminar Teknologi Informasi (SNATI) hal. 24.

Raselawati Ader, 2011. Pengaruh Perkembangan Usaha Kecil Menengah Terhadap Pertumbuhan Ekonomi pada sector UKM di Indonesia, Jakarta, FE Universitas Islam Negeri Syarif Hidayatullah, hal. 12.

Republika.co.id/berita/Koran/ekonomi-koran/16/11/22/oh1a8b4-umkm-sukses-mengurangipengangguran 
International Journal of Economics, Business and Accounting Research (IJEBAR)

Peer Reviewed - International Journal

Vol-4, Issue-2, 2020 (IJEBAR)

E-ISSN: 2614-1280 P-ISSN 2622-4771

http://jurnal.stie-aas.ac.id/index.php/IJEBAR

Serbanica Daniel, Militaru Gheorge, 2008. Corporate Social Responsibility and Competitiveness.

Soegiastuti Janti, 2012. Penerapan Strategi Corporate Social Responsibility (CSR) Untuk Memperkuat Usaha Mikro, Kecil, dan Menengah (UMKM). Media Ekonomi dan Manajemen, Vol. 25 No. 1.

Suherman Maman, 2004. Peranan Corporate Sosial Responsibility (CSR) Dalam Menurunkan Angka Kemiskinan di Jawa Barat. Jurnal Mimbar, Vol. XXII No. 3- Juli-September, hal. 317-332

Supomo Bambang dan Indriantoro Nur, 2002, Metodologi Penelitian Bisnis, Cetakan Kedua, Yogyakara; Penerbit BFEE UGM.

Supranto, J. 2003. Metode Riset Aplikasi Dalam Pemasaran. Edisi Revisi Ketujuh.Yogyakarta: Rineka Cipta. Business Ethics

Turyakira Peter, Venter Elmarie and Smith Elroy, 2013. The Impact of Corporate Social Responsibility Factors on the Competitiveness of Small and Medium-Sized Enterprises. Journal SAJEMS NS.

Turyakira Peter, Venter Elmarie, and Smith Elroy, 2012. Corporate Social Responsibility for SMEs: A Proposed Hypothesed Model. African Journal of Business, Vol. 6, Issue 2. May- Augustust.

Zhao Zhonghua, Meng Fanchen, He Yin, and Gu Zhouyang, 2019. The Influence of Corporate Social Responsibility on Competitive Advantage with Multiple Mediations from Social Capital and Dynamic Capabilities. Sustainability Journal. 